\title{
HUBUNGAN POLA MAKAN DENGAN KEJADIAN DIABETES MELLITUS DI RUMAH SAKIT ISLAM SITTY MARYAM KECAMATAN TUMINTING KOTA MANADO
}

\author{
Stefanus Timah \\ Universitas Pembangunan Indonesia \\ Alamat Korespondensi :(stefanustimah@gmail.com/ 081241156778)
}

\begin{abstract}
ABSTRAK
Penyakit Diabetes Melitus (DM) merupakan penyakit seumur hidup dan tidak dapat disembuhkan, akan tetapi kadar gula darah dapat diminimalkan/ dikendalikan sedemikian rupa sehingga selalu sama dengan kadar glukosa responden normal atau dalam batas normal. Kadar glukosa yang tidak terkendali atau tidak tertangani dengan baik bisa mengakibatkan berbagai komplikasi. Tujuan Penelitian Diketahui hubungan pengetahuan pola makan dengan Kejadian Penyakit Diabetes Mellitus di Rumah sakit Islam Sitty Maryam Kecamatan Tuminting Kota Manado.Jenis penelitian yaitu deskriptif analitik,waktu pada bulan Mei 2019 dan tempat penelitian di Rumah sakit Islam Sitty Maryam Kota Manado. Uji statistik yang digunakan adalah Chi Square dengan derajat kepercayaan $95 \%$ bila $\propto<0,05$. Hasil penelitian terdapat hubungan dengan kejadian Diabetes Mellitus di Rumah Sakit Islam Sitty Maryam dan terdapat hubungan Pola Makan dengan kejadian Diabete Mellitus pada anak di Rumah Sakit Islam Sitty Maryam. Saran dalam penelitian ini yaitu Diharapkan hasil penelitian ini menjadi bahan untuk menambah pengetahuan dalam upaya mencegah terjadinya penyakit Diabetes Mellitus dan menambah pengetahuan masyarakat tentang pola makan agar tidak terjadi penyakit diabetes mellitus.
\end{abstract}

Kata Kunci: Kejadian Diabetes Mellitus, Pola Makan

\section{PENDAHULUAN}

Menurut data World health Organisation (WHO) tahun 2016 angka penderita penyakit diabetes mellitus terbanyak diderita di negaranegara berkembang dan negara maju kuang lebih ada 30 juta penderita Diabetes mellitus didunia yang menderita penyakit ini dikarenakan factor keturunan dan gaya hidup masyarakat (WHO, 2016).

Pada dasarnya, diabetes mellitus disebabkan hormon insulin penderita tidak mencukupi atau tidak dapat bekerja normal. Hormon insulin tersebut mempunyai peranan utama untuk mengatur kadar gula (glukosa). Glukosa dalam darah ukuran normalnya sekitar 60-120 mg/dl waktu puasa dan dibawa $200 \mathrm{mg} / \mathrm{dl}$ pada dua jam sesudah makan (Darmono, 2014)

Penelitian terakhir yang di lakukan oleh LITBANGKES DEPKES di Indonesia pada tahun 2015 jumlah penderita mencapai 5,7\% dan tahun 2016 diperkirakan mencapai minimal 7 juta responden, dimana baru $50 \%$ yang sadar mengidapnya dan diantara mereka baru sekitar $30 \%$ yang datang berobat teratur (Suyono, 2013)

Hasil data dari Rekam Medik di RSI Sitty Maryam Manado pada tahun 2018 dari bulan Februari 2018, jumlah pasien rawat inap yang menderita penyakit diabetes melitus adalah sebanyak 40 responden (Rekam Medik RSI Sitty Maryam, 2018). Penyakit diabetes mellitus merupakan suatu penyakit kronis, berbagai perubahan kesehatan dapat menimbulkan gangguan baik fisik maupun psikologis. Masalah fisik misalnya pasien kelelahan, poliuria, polidipsi, luka pada kulit yang lama sembuh dan pandangan yang kabur (Brunner, 2012). Stress psikologis dapat timbul ketika seseresponden terdiagnosa diabetes melitus yang ditandai oleh ketidakseimbangan fisik, sosial dan psikologis dan hal ini berlanjut menjadi perasaan gelisah, takut, cemas bahkan depresi yang akhirnya dapat memperberat keadaan sakitnya (Yunir, 2012)

Dampak penyakit diabetes melitus secara fisik seperti pasien akan mudah mengalami kelelahan. Dampak psikologis yang ditimbulkan seperti pasien akan mengalami gelisah, stress bahkan depresi. Penyesuaian diri terhadap penyakit kronis seperti diabetes mellitus dapat menyebabkan stress (Basuki, 2014). Stress emosional memberikan dampak negatif terhadap pengendalian diabetes karena peningkatan hormon stress akan meningkatkan kadar glukosa darah, khususnya bila asupan makanan dan pemberian insulin yang tidak terkontrol. Pada saat terjadi stress emosional pasien dapat 
mengubah pola makan, latihan dan penggunaan obat yang biasanya dipatuhi menjadi diabaikan. Keadaan ini akan menimbulkan hiperglikemia atau bahkan hipoglikemia (Suyono, 2013).

Dampak yang ditimbulkan dari penyakit diabetes mellitus yakni dampak fisik dan juga dampak psikologis. Ada beberapa faktor risiko yang menyebabkan timbulnya penyakit diabetes mellitus seperti pola makan dan aktivitas fisik. Pola makan merupakan determinan terjadinya obesitas yang secara tidak langsung menyebabkan penyakit diabetes mellitus. Selain pola makan faktor aktivitas fisik berpengaruh terhadap kejadian diabetes mellitus karena sebagian besar penderita diabetes mellitus merupakan masyarakat yang memiliki aktivitas kurang dan hanya melakukan olahraga satu kali dalam seminggu (Subekti, 2014)

Dari uraian di atas, maka peneliti merasa tertarik untuk mengetahui lebih dalam tentang Analisi Pola Makan dengan Kejadian penyakit diabetes mellitus di RSI Sitty Maryam manado.

\section{BAHAN DAN METODE}

Lokasi, Populasi dan Sampel

Penelitian ini telah dilaksanakan di rungan interna rawat jalan RSI Sitty Maryam Manado. dilaksanakan pada bulan Mei 2019. Populasi dalam penelitian ini adalah seluruh pasien diabetes mellitus berjumlah 40 pasien di RSI Sitty Maryam manado. Dalam penelitian ini diambil total populasi dari pasien Diabetes mellitus di RSI Sitty Maryam Manado dengan jumlah 40 responden.

\section{Pengumpulan Data}

1. Data Primer

Data yang dikumpulkan dari hasil pengamatan langsung dan ditabulasi serta dimasukkan kedalam hasil dan pembahasan

2. Data Sekunder

Data Sekunder adalah Data yang diperoleh dari di RSI Sitty Maryam manado.

\section{Pengolahan Data}

1. Editing

Adalah upaya untuk memriksa kembali kebenaran data yang diperoleh atau dikumpulkan. Editing dapat dilakukan pada tahap pengumpulan data atau setelah data terkumpul.

2. Coding

Merupakan kegiatan pemberian kode numerik (angka) terhaddap data yang terdiri atas beberapa kategori. Pemberian kode ini sangat penting bila pengolahan dan analisis data menggunakan komputer. Biasanya dalam pemberian kode dibuat juga daftar kode dan artinya dalam satu buku (code book) untuk memudahkan kembali melihat lokasi danarti suatu kode dari suatu variabel.

3. Entri data

Data entri adalah kegiatan memasukkan data yang telah dikumpulkan ke dalam master atau database komputer, kemudian membuat distribusi frekuensi sederhana atau bisa juga dengan membuat tabel kontigensi (Hidayat, 2011).

\section{Analisis Data}

1. Analisa Univariat

Analisa untuk mengetahui presentasi dari masing-masing variabel yang akan diteliti. Data univariant yaitu : gaya hidup dan kejadian diabetes mellitus.

2. Analisa Bivariat

Analisa bivariat dilakukan untuk melihat adanya hubungan antara variabel dan digunakan uji statistik. Setelah itu data di input dengan software komputer untuk di dianalisa dengan mengunakan uji statistik menggunakan uji Chi-Square dengan nilai signifikasi $\alpha<0.05$.

\section{HASIL PENELITIAN}

1. Analisis Univariat

Tabel 1. Distribusi karakteristik responden di Rumah Sakit Islam Sitty Maryam Kecamatan Tuminting Kota Manado. $(\mathrm{n}=40)$.

\begin{tabular}{|c|c|c|}
\hline Karakteristik & $\mathrm{n}$ & $\%$ \\
\hline PNS & 23 & 57,5 \\
SWASTA & 10 & 25 \\
WIRASWASTA & 7 & 17,5 \\
\hline Umur & & \\
$30-40$ & 9 & 22,5 \\
$41-50$ & 11 & 27,5 \\
$>50$ & 20 & 50 \\
\hline Pendidikan & & \\
SMP & 10 & 25 \\
SMA & 12 & 30 \\
SI & 11 & 27,5 \\
S2 & 7 & 17,5 \\
\hline
\end{tabular}

Berdasarkan tabel 1. diatas, dari 40 responden menunjukkan pekerjaan yang dimiliki responden dalam penelitian ini sebagian besar bekerja sebagai PNS yaitu $57,5 \%$ atau sebanyak 23 responden dan paling sedikit berprofesi sebagai Wiraswasta sebesar $17,5 \%$ atau sebanyak 7 responden. tingkat umur responden yang paling banyak adalah responden dengan kategori umur $>50$ 
tahun berjumlah 20 responden $(50 \%)$, selanjutnya adalah responden dengan umur 41-50 tahun berjumlah 11 responden $(27,5 \%)$. Sedangkan jumlah responden yang paling sedikit adalah responden dengan usia 30-41 tahun berjumlah 9 responden $(22,5 \%)$. tingkat pendidikan responden yang paling banyak adalah SMA berjumlah 12 responden (30\%), diikuti SI berjumlah 11 responden (27,5\%), diikuti SMP berjumlah 10 responden (25\%) dan yang paling sedikit S2 berjumlah 7 responden $(17,5 \%)$.

2. Analisis Bivariat

Tabel 2. Hubungan Pola makan dengan kejadian diabetes mellitus

\begin{tabular}{|c|c|c|c|c|c|c|}
\hline \multirow{3}{*}{$\begin{array}{c}\begin{array}{c}\text { Pola } \\
\text { makan }\end{array} \\
\text { Baik }\end{array}$} & \multicolumn{6}{|c|}{ Diabetes Melitus } \\
\hline & \multicolumn{2}{|c|}{$\begin{array}{c}\text { DM } \\
\text { Normal }\end{array}$} & \multicolumn{2}{|c|}{ DM Tinggi } & \multicolumn{2}{|c|}{ Total } \\
\hline & 7 & 17.5 & 4 & 10.0 & 11 & 27.5 \\
\hline $\begin{array}{c}\text { Kurang } \\
\text { baik }\end{array}$ & 4 & 10.0 & 25 & 62.5 & 29 & 72.5 \\
\hline Total & 11 & 100.0 & 29 & 72.5 & 40 & 100.0 \\
\hline
\end{tabular}

Berdasarkan tabel 2. diatas terlihat bahwa Pola makan baik maka yang mengalami diabetes melitus sebanyak 4 responden atau $10 \%$ dan tidak mengalami diabetes melitus sebanyak 7 responden atau $17,5 \%$. Pada gaya hidup kurang baik maka perawat yang mengalami diabetes mellitus sebanyak 25 responden atau $62,5 \%$ sedangkan tidak mengalami diabetes melitus sebanyak 4 responden atau $10 \%$. Berdasarkan hasil uji chi square diperoleh nilai $p=0,004<\alpha=0,05$ sehingga dapat disimpulkan bahwa ada hubungan bermakna antara pola makan dengan kejadian diabetes mellitus.

Hasil penelitian ini diperoleh nilai OR (Odds Ratio) 4,200 yang berarti bahwa jika pola makan itu baik maka akan berpeluang 4 kali untuk menurunkan kejadian diabetes mellitus, demikian pula sebaliknya, jika Pola makan kurang baik maka akan berpeluang 4 kali akan meningkatkan penyakit diabetes mellitus.

\section{PEMBAHASAN}

1. Pola Makan Pasien Diabetes Mellitus

Dari tabel 2 menunjukan bahwa sebagian besar responden mempunyai gaya hidup yang baik sebanyak 11 responden $(27,5 \%)$, sedangkan pola makan kurang baik berjumlah 29 responden $(72,5 \%)$. Sehingga dapat disimpulkan bahwa responden dengan pola makan yang kurang lebih besar dari pada reseponden yang memilki pola makan yang baik.

Pola makan yang cenderung menjauhkan konsep makan seimbang dapat berdampak negatif terhadap kesehatan dan gizi. Pola konsumsi makanan yang dapat mengakibatkan diabetes mellitus yaitu pola konsumsi makanan yang mengandung jumlah kalori yang berlebih, tinggi lemak jenuh dan gula, rendah serat dan rendah gizi mikro akan menyebabkan masalah kegemukan, gizi lebih, serta meningkatkan radikal bebas yang akhirnya mengakibatkan perubahan pola penyakit, dari infeksi kepenyakit kronis non infeksi atau memicu munculnya penyakit degeneratif (Suiraoka, 2012)

Penelitian ini juga sejalan dengan penelitian yang dilakukan oleh Devita 2014 yang berjudul hubungan antara pola makan dengan kejadian diabetes mellitus di poliklinik penyakit dalam RSUD Tugurejo Semarang yang menyatakan bahwa ada hubungan yang signifikan antara pola makan dengan kejadian diabetes mellitus, dimana makanan adalah merupakan sumber dari energi yang dibutuhkan oleh tubuh, akan tetapi juga dapat menjadi sumber penyakit bagi tubuh jika tidak dikonsumsi dengan pola makan yang sehat.

Pola makan adalah jenis dan jumlah bahan makan yang dikonsumsi, pola makanan, termasuk dari gaya hidup dalam memilih tempat makan dan jenis makanan yang dikonsumsi merupakan salah satu faktor penyebab terjadinya diabetes mellitus. Perubahan pola makan dalam hal komsumsi makanan dipicu oleh perbaikan/peningkatan disektor pendapatan (ekonomi), kesibukan kerja yang tinggi dan promosi makanan yang trendy ala barat, namun tidak diimbangi dengan pengetahuan dan kesadaran gizi, akhirnya badan akan berubah menjadi tinggi lemak jenuh dan gula, rendah serat dan rendah zat gizi mikro.

2. Kejadian Diabetes Melitus

Dari tabel 3 diatas menunjukan bahwa responden yang mengalami diabetes mellitus normal berjumlah 11 responden $(27,5 \%)$ dan yang diabetes mellitus tinggi berjumlah 29 responden $(72,5 \%)$. Dapat disimpulkan bahwa responden yang tidak diabetes mellitus tinggi lebih besar dari pada responden yang mengalami diabetes mellitus tinggi. 
Pola makan di kota-kota telah bergeser dari pola makan tradisional yang mengandung banyak karbohidrat dan serat dari sayuran, ke pola makan kebaratbaratan, dengan komposisi makanan yang terlalu banyak mengandung protein, lemak, gula, garam dan mengandung sedikit serat. Komposisi makanan seperti ini terutama terdapat pada makanan siap santap yang akhir-akhir ini sangat digemari terutama oleh anak-anak muda. Di samping itu cara hidup yang sangat sibuk dengan pekerjaan dari pagi sampai sore bahkan kadangkadang sampai malam hari duduk di belakang meja menyebabkan tidak adanya kesempatan untuk berekreasi atau berolahraga. Pola hidup berisiko seperti inilah yang menyebabkan tingginya kekerapan penyakit jantung koroner, DM dan hiperlipidemia (Tambunan, 2009).

Penyakit Diabetes Melitus merupakan penyakit degeneratif yang sangat terkait pola makan. Pola makan merupakan gambaran mengenai macammacam, jumlah dan komposisi bahan makanan yang dimakan tiap hari oleh seseresponden. Pola makan di perkotaan dengan pola diet yang tinggi lemak, garam, dan gula, keseringan menghadiri resepsi/pesta, mengakibatkan masyarakat cenderung mengkonsumsi makanan secara berlebihan mengakibatkan berbagai penyakit termasuk DM. WHO memprediksi kenaikan jumlah penyandang Diabetes millitus di Indonesia dari 8,4 juta pada tahun 2010 menjadi sekitar 21,3 juta pada tahun 2030.

Penelitian ini sesuai dengan hasil penelitian Sartika Sumangkut pada tahun 2015 tentang hubungan pola makan dengan kejadian diabetes mellitus di Poliklinik Interna BLU RSUP. Prof. Dr. R. D. Kandou Manado. Hasil penelitian yang didapat pada tingkat kepercayaan 95\% menunjukkan nilai $p=0,000$. Nilai $p$ ini lebih kecil dari nilai $\alpha=0,05$. Kesimpulan dari penelitian ini yaitu terdapat hubungan pola makan dengan kejadian diabetes mellitus tipe-2 di Poliklinik Interna BLU RSUP. Prof. Dr. R. D. Kandou Manado. Saran peran penting dari tenaga medis dan para medis serta ahli gizi untuk terus memberikan informasi kepada pasien Diabetes mellitus yang berobat di Poliklinik Interna BLU RSUP. Prof. Dr. R. D. Kandou Manado, sehingga dapat mengatur pola makan dengan baik.

Pola makan sangat berhubungan dengan berbagai macam penyakit, pola makan yang berlebihan akan mempengaruhi metabolism tubuh, faktorfaktor yang dapat menyebabkan penyakit Diabetes mellitus salah satu adalah ola makan yang berlebihan.

Pola makan yang dipersyaratkan oleh pakar kesehatan yaitu ola makan yang seimbang artinya pola makan yang memenuhi syarat-syarat pemenuhan gizi dan protein.

Hubungan Pola Makan dengan Kejadian Diabetes Mellitus Berdasarkan tabel 4 diatas terlihat bahwa pola makan baik maka yang mengalami diabetes melitus sebanyak 4 responden atau 10\% dan tidak mengalami diabetes melitus sebanyak 7 responden atau $17,5 \%$. Pada gaya hidup kurang baik maka perawat yang mengalami diabetes melitus sebanyak 25 responden atau $62,5 \%$ sedangkan tidak mengalami diabetes melitus sebanyak 4 responden atau $10 \%$. Berdasarkan hasil uji chi square diperoleh nilai $p=0,004<\alpha=0,05$ sehingga dapat disimpulkan bahwa ada hubungan bermakna antara gaya hidup dengan kejadian diabetes melitus.

Hasil penelitian ini diperoleh nilai OR (Odds Ratio) 4,200 yang berarti bahwa jika pola makan itu baik maka akan berpeluang 4 kali untuk menurunkan kejadian diabetes mellitus.

Pola makan seseresponden dapat juga dilihat dari aktivitas fisik seperti olahraga, kurang berolah raga beresiko mengalami diabetes mellitus Hasil penelitian ini sejalan dengan hasil penelitian yang dilakukan oleh Riska sidaz 2016 dengan penelitian yang berjudul hubungan aktifitas fisik dengan kejadian diabetes mellitus di RSUD perahabatan, yang menunjukkan bahwa adanya pengaruh besar olahraga terhadap kejadian diabetel mellitus. Karena dengan olahraga tubuh akan lebih sehat. Olahraga akan memperbanyak jumlah dan meningkatkan aktivitas reseptor insulin dalam tubuh dan juga meningkatkan penggunaan glukosa. Hal ini menunjukkan bahwa olahraga sangatlah berpengaruh terhadap tingkat kesehatan seseresponden. Dimana olahraga adalah aktivitas untuk melatih tubuh. Berolahraga dengan teratur dapat membantu menurunkan kadar berat badan dan mengendalikan kadar gula darah. Selain perlu mencapai gula darah dan mempertahankan gula darah mendekati normal, diabetisi juga perlu mencapai dan mempertahankan lemak darah serta tekanan darah yang normal dan dengan 
menu makan yang seimbang sesuai kebutuhan gizi. Karena dengan olahraga tubuh akan lebih sehat. Olahraga akan memperbanyak jumlah dan meningkatkan aktivitas reseptor insulin dalam tubuh dan juga meningkatkan penggunaan glukosa. Adapun manfaat olahraga yaitu untuk: Menurunkan kadar gula darah, Mencegah kegemukan, Menurunkan lemak darah (kolesterol), Mencegah tekanan darah tinggi, Mengurangi resiko penyakit jantung coroner, Meningkatkan kualitas hidup dan kemampuan kerja. Perinsip olahraga yaitu: (Nabyl, 2012) Frekuensi 3-5 kali seminggu secara teratur, Intensitas olahraga ringan dan sedang Durasi 30-60 menit setiap latihan Jenis latihan yang dianjurkan adalah aerobik, seperti jalan, joging, berenang, bersepeda dan lain-lain.

Berdasarkan hasil uji chi square diperoleh nilai $p=0,004<\alpha=0,05$ sehingga dapat disimpulkan bahwa ada hubungan bermakna antara pola makan dengan kejadian diabetes mellitus, dari hasil penelitian diketahui responden dengan pola makan kurang baik dan mengalami diabetes melitus lebih besar daripada yang memiliki pola makan yang baik dan mengalami diabetes melitus, gaya hidup kurang baik seperti kurang berolahraga dan pola makan yang tidak sehat. Hal ini menunjukkan bahwa responden dengan pola makan kurang sehat lebih beresiko terkena diabetes mellitus dibandingkan responden dengan pola makan yang sehat.

\section{KESIMPULAN}

1. Dari hasil penelitian terlihat bahwa lebih banyak responden yang memiliki Pola makan kurang baik dari pada pola makan baik.

2. Dari hasil penelitian terlihat bahwa lebih banyak responden yang mengalami diabetes mellitus tinggi dari pada yang menderita diabetes mellitus normal

3. Dari hasil analisis disimpulkan bahwa ada hubungan bermakna antara Pola Makan dengan kejadian diabetes mellitus.

\section{SARAN}

1. Bagi Penderita Diabetes Melitus

Hasil penelitian diharapkan dapat menambah pengetahuan Penderita tentang diabetes melitus dan upaya pencegahan serta pengobatannya.

2. Bagi Tenaga kesehatan

Hasil penelitian ini diharapkan dapat menjadi masukan bagi petugas kesehatan dalam melaksanakan upaya pencegahan sesuai kondisi masyarakat sehingga penyakit diabetes bisa diturunkan.

3. Bagi masyarakat

Penelitian ini menjadi pengalaman berharga dan menambah pengetahuan bagi masyarakat serta dapat mengetahui tentang upaya pengendalian pencegahan dan pengobatan diabetes mellitus.

\section{DAFTAR PUSTAKA}

Basuki, 2014. Teknik Penyuluhan Diabetes Melitus. FKUI

Darmono, 2014. Diabetes Melitus dan Klasifikasi Pancreas. Medan.

Damayanti. (2012). Waspadai Kegemukan Pada Anak. [terhubungberkala]. www.keluargasehat.com.

Hidayat, at. all, 2011. Gemuk Belum Tentu Sehat. [terhubungberkala]. www.indomedia.com .

Nursalam, 2012. Konsep dan Penerapan Metodologi Penelitian Ilmu keperawatan. Jakarta: salemba medika.

Subekti, 2014. .Konseus Pengelolaan Diabetes Melitus tipe 2. PB Parkeni.

Susan , 2012. Diabetes Care and Patien Education in CME Resource. California.

Suyono, 2013. Pengobatan Diabetes Melitus. Jakatra: naskah lengkap symposium.

Tambunan, 2009. Perawatan Kaki Diabetes Melitus. Jakarta: FKUI.

Waspadji S. Yunir. 2012. Pengelolaan Kaki Diabetik. Jakarta: naskah diabetes

World Health Organisation. 2016. Diabetes Mellitus. Second report. Technical report. Geneva: WHO.

Yuniar, 2012. Dampak psikologi dan fisiologi penyakit diabetes mellitus pada penderita PT Gajah Mada, Jakarta. 